\title{
ANALISIS FAKTOR PERILAKU DAN JARAK FASILITASKESEHATAN TERHADAP PEMANFAATAN POSYANDU LANSIA HIPERTENSI DI DESA MUNTOI KECAMATAN PASSI BARAT
}

\author{
Ake R. C. Langingi ${ }^{1}$, Sudirman², Grace I. V. Watung ${ }^{3}$ \\ ${ }^{1}$ Prodi S1 Keperawatan STIKES Graha Medika Kotamobagu \\ ${ }^{2}$ Prodi S1 Kesehatan Masyarakat STIKES Graha Medika Kotamobagu \\ ${ }^{3}$ Prodi Profesi Ners STIKES Graha Medika Kotamobagu \\ Email: langingiake@gmail.com
}

\begin{abstract}
The advanced period is the process of slowly disappearing tissue to repair itself or replace and maintain normal tissue function of the body. The elderly is vulnerable to hypertension. This certainly has an impact on the risk of experiencing health problems, one of which is a disease that is often found in the elderly, namely hypertension. Objective to determine the relationship between behavior and distance of health facilities with the use of posyandu for elderly in East Muntoi Village, West Passi District, Bolaang Mongondow Regency. This type of research is a quantitative study with a cross sectional study approach. The population in this study were all elderly in Muntoi Village, while the sample was also 40 elderly. Based on the results of the correlation test between behavior variables and facility distance with the use of the elderly posyandu using the Chi Square test, it shows that there is a relationship between the distance of health facilities and the utilization of posyandu for the elderly $(p=0.000)$. Behavioral variables, health insurance, and distance to elderly posyandu facilities have a positive impact on the utilization of posyandu for the elderly in Muntoi Village, Passi Barat subdistrict. Most of the $60 \%$ elderly who are obliged to attend Posyandu Lansia in Muntoi village is $\geq$ 69 years old and $40 \%$ are 60-68 years old. Most of the elderly cannot access posyandu for the elderly if they have a distance of $\geq 500 \mathrm{M}$ from their place of residence. It anticipated that providers and implementers of elderly health services could provide mobilization support for every elderly in Muntoi village to get god purpose and efficient health services, to create a better health status for the elderly.
\end{abstract}

Keywords: Behavior, Facility Distance, Utilization of The Integrated Healthcare by Elderly.

\begin{abstract}
ABSTRAK
Masa lanjut usia yaitu proses menghilangnya secara perlahan-lahan kemampuan jaringan untuk memperbaiki diri atau mengganti dan mempertahankan fungsi normal jaringan tubuh. Masa lansia rentan dengan hipertensi. Ini tentunya berdampak pada resiko mengalami gangguan kesehatan salah satunya penyakit yang sering dijumpai pada lansia yaitu hipertensi. Tujuan penelitian untuk mengetahui hubungan perilaku dan jarak fasilitas kesehatan dengan pemanfaatan posyandu lansia di desa muntoi Timur, Kecamatan Passi Barat Kabupaten Bolaang Mongondow. Jenis penelitian ini adalah penelitian kuantitatif dengan pendekatan cross sectional study. Populasi dalam penelitian ini adalah seluruh lanjut usia di Desa Muntoi, sedangkan sampel juga sebanyak 40 lanjut usia. Berdasarkan hasil uji kolerasi antara variabel perilaku dan jarak fasilitas dengan pemanfaatan posyandu lansia menggunakan uji Chi Square, menunjukan terdapat hubungan antara jarak fasilitas
\end{abstract}


kesehatan dengan pemanfaatan posyandu lansia $(\mathrm{p}=0,000)$. Variabel perilaku, Jaminan kesehatan dan jarak fasilitas posyandu lansia berdampak positif terhadap pemanfaatan posyandu lansia di Desa Muntoi kecamatan Passi barat. Lansia yang wajib mengikuti posyandu lansi di desa Muntoi sebagian besar $60 \%$ berumur $\geq 69$ tahun dan $40 \%$ lainnya telah berumur 60-68 tahun. Sebagian besar lansia tidak dapat mengakses posyandu lansia apabila memiliki jarak yang $\geq 500 \mathrm{M}$ dari tempat tinggalnya. Diharapkan bagi penyedia dan pelaksana layanan kesehatan lansia agar memberi dukungan mobilisasi kepada setiap lansia di desa Muntoi agar mendapatkan pelayanan kesehatan yang efektif dan efisien, demi terciptanya drajat kesehatan lansia yang lebih baik.

Kata kunci: Perilaku, Jarak Fasilitas, Pemanfaatan Posyandu Lansia.

\section{PENDAHULUAN}

Keberhasilan pembangunan manusia dikatakan berhasil apabila usia harapan hidup penduduk semakin bertambah, peningkatan usia harapan hidup berdistribusi langsung terhadap peningkatan jumlah LANSIA (> 60 Tahun) setiap tahunnya. Menurut World Health Organization (WHO) usia manusia di kategorikan dengan klaterisasi sebagai berikut; middle age 45-59, elderly age 60-74, old age7590 , very old $>90$ tahun $^{1}$.

Masa lanjut usia (lansia) merupakan masa dimana disebut dengan istilah penuaan (proses terjadinya tua) yaitu proses menghilangnya secara perlahan-lahan kemampuan jaringan untuk memperbaiki diri atau mengganti dan mempertahankan fungsi normalnya sehingga tidak dapat bertahan terhadap infeksi dan memperbaiki kerusakan yang diderita. Seiring dengan proses menua tersebut, tubuh akan mengalami berbagai masalah kesehatan atau yang biasa disebut sebagai penyakit degeneratif. Lanjut usia dikatakan sebagai tahap akhir perkembangan pada daur kehidupan manusia.
Untuk itu para lansia harus mendapatkan perhatian serius terhadap masalah kesehatannya, salah satunya lewat program posyandu lansia ${ }^{2}$. Undang-undang pasal 138 tentang kesehatan lansia dan penyandang catat dalam pasal (1) Upaya pemeliharaan kesehatan bagi lanjut usia harus ditujukan untuk menjaga agar tetap hidup sehat dan produktif secara sosial maupun ekonomis sesuai dengan martabat kemanusiaan. (2) Pemerintah wajib menjamin ketersediaan fasilitas pelayanan kesehatan dan memfasilitasi kelompok lanjut usia untuk dapat tetap hidup mandiri dan produktif secara sosial dan ekonomis ${ }^{3}$.

Penderita hipertensi memiliki perilaku yang kurang baik dalam melakukan manajemen hipertensi. Perilaku penderita hipetensi dalam melaksanakan aktivitas fisik dan diet hipertensi secara teratur dan rutin dipengaruhi oleh pengetahuan yang kurang maupun perilaku penderita hipertensi itu sendiri ${ }^{4}$. Pengetahuan penderita hipertensi yang kurang dikarenakan kurangnya informasi yang diperoleh oleh penderita, baik dari petugas kesehatan maupun 
media cetak atau elektronik. Perilaku penderita hipertensi yang kurang patuh dikarenakan kejenuhan serta tidak terbiasanya penderita hipertensi untuk menjalankan aktivitas fisik dan diet hipertensi, yang disebabkan oleh budaya responden itu sendiri yang sudah melekat sejak lahir sehingga sangat sulit sekali untuk dihilangkan ${ }^{5}$.

Pengadaan posyandu lanjut usia bertujuan untuk meningkatkan kualitas sumber daya lanjut usia. Diharapkan dengan adanya posyandu lanjut usia, akan tercapai lanjut usia yang sehat, masih produktif, serta tidak sakit-sakitan ${ }^{6}$. Dalam kegiatan posyandu ini dukungan keluarga sangat berperan karena keluarga merupakan lingkungan yang paling dekat dengan lansia ${ }^{7}$.

Hipertensi merupakan kejadian dimana tekanan darah sistolik >140 $\mathrm{mmHg}$ dan tekanan diastolic >90 mmHg dengan 2 kali pemeriksaan dengan selang waktu 5 menit pada kondisi tubuh yang cukup istirahat/tenang. Hipertensi atau nama lainnya the silent killer menyebabkan setiap orang yang menderitanya kurang mengetahui gejala yang di alaminya ${ }^{8}$. Pencegahan penyakit Hipertensi dapat dilakukan dengan mengkonsumsi obat secara rutin dan mengatur pola hidup dengan menggunakan pendekatan pola hidup sehat dan seimbang ${ }^{3}$.

Pemanfaatan puskesmas dan pelaksanaan programnya sangat bergantung pada fasilitas yang diberikan atau disediakan kepada masyarakat, demikian motivasi petugas tenaga kesehatan juga akan berdampak dalam memberi pelayanan, program posyandu lansia saat ini merupakan program utama yang dilaksanakan di Puskesmas untuk meningkatkan drajat kesehatan masyarakat lanjut usia ${ }^{9}$.

Pada saat pengambilan data awal tanggal 22 januari 2020 di Puskesmas Passi Barat terdapat 40 pasien lansia, yang tercatat 35 orang lansia yang menderita hipertensi dan yang aktif berkunjung ke Posyandu hanya 10 orang. Melihat data yang didapatkan dari Puskesmas Passi Barat peneliti berkesimpulan bahwa kesadaran akan pentingnya berkunjung ke Posyandu Lansia sangatlah kurang pada lansia di Desa Muntoi terbukti hanya 10 lansia yang melakukan kunjungan Posyandu Lansia. Ini tentunya berdampak pada resiko mengalami gangguan kesehatan salah satunya penyakit yang sering dijumpai pada lansia yaitu hipertensi dengan alasan inilah peneliti tertarik melakukan penelitian hubungan perilaku dan jarak fasilitas kesehatan dengan pemanfaatan posyandu lansia hipertensi di Desa Muntoi Kecamatan Passi Barat Kabupaten Bolaang Mongondow.

\section{METODE PENELITIAN}

Penelitian ini dilakukan menggunakan jenis Kuantitatif analytic dengan metode cross sectional study menggunakan pendekatan observational dimana pengumpulan data dilakukan pada waktu yang sama. Populasi pada penelitian ini adalah seluruh lansia Hipertensi yang tercatat di posyandu lansia di Desa Muntoi 
Timur Kecamatan Passi Barat Wilayah berjumlah 40 lansia. Sampel penelitian berjumlah 40 orang ditentukan menggunakan teknik total population sampling. Analisis data dilakukan dalam bentuk analisis univariate dan bivariate. Analisa univariate dilakukan untuk menghasilkan atau menginterprestasikan data secara deskriptif, dalam bentuk frekuensi dan persentase. Analisis bivariate dilakukan untuk mengetahui hubungan variabel yang diteliti.

\section{HASIL DAN PEMBAHASAN}

\section{Hasil Penelitian}

\section{Karakteristik Responden}

Tabel 1. Distribusi Berdasarkan Jenis Kelamin

\begin{tabular}{lcr}
\hline Jenis Kelamin & $\mathrm{n}$ & $\%$ \\
\hline Laki-Laki & 9 & 22,5 \\
Perempuan & 31 & 77,5 \\
\hline Total & 40 & 100,0 \\
\hline
\end{tabular}

Berdasarkan Tabel 1 diatas menunjukkan bahwa dari 40 responden diketahui jumlah responden yang berjenis kelamin perempuan yaitu 31 lansia $(77,5 \%)$ dan yang berjenis kelamin laki-laki berjumlah 9 lansia $(22,5 \%)$.

Tabel 2. Distribusi Berdasarkan Umur

\begin{tabular}{lcr}
\hline Umur Responden & $\mathrm{n}$ & $\%$ \\
\hline $60-69$ tahun & 24 & 60,0 \\
$>69$ tahun & 16 & 40,0 \\
\hline Total & 40 & 100,0 \\
\hline
\end{tabular}

Berdasarkan Tabel 2 diatas menunjukkan bahwa sebagian besar responden berusia 60-69 tahun yaitu sebanyak 24 lansia $(60,0 \%)$, dan umur $>69$ tahun sebanyak 16 lansia $(40,0 \%)$.
Tabel 3. Distribusi Berdasarkan Jarak Fasilitas Kesehatan

\begin{tabular}{lcr}
\hline Jarak Fasilitas kesehatan & $\mathrm{n}$ & $\%$ \\
\hline$>500 \mathrm{~m}$ & 14 & 35,0 \\
$<500 \mathrm{~m}$ & 26 & 65,0 \\
\hline Total & 40 & 100,0 \\
\hline
\end{tabular}

Berdasarkan Tabel 3 diatas menunjukkan bahwa dari 40 responden diketahui 26 lansia $(65,0 \%)$ memiliki Jarak <500m dan 14 lansia $(35,0 \%)$ memiliki jarak $>500 \mathrm{~m}$.

Tabel 4. Distribusi Berdasarkan Pemanfaatan Posyandu Lansia

\begin{tabular}{lcr}
\hline Pemanfaatan & $\mathrm{n}$ & $\%$ \\
\hline Tidak Memanfaatkan & 15 & 37,5 \\
Memanfaatkan & 25 & 62,5 \\
\hline Total & 40 & 100,0 \\
\hline
\end{tabular}

Berdasarkan Tabel 4 diatas menunjukkan bahwa 25 lansia (62,5\%) memanfaatkan Posyandu Lansia dan 15 lansia (37,7\%) Tidak Memanfaatkan Posyandu Lansia.

\section{Analisis Jarak Fasilitas Kesehatan dan Pemanfaatan Posyandu Lansia}

Tabel 5. Distribusi Jarak Fasilitas Kesehatan terhadap Pemanfaatan Posyandu Lansia

\begin{tabular}{lccccc}
\hline \multirow{2}{*}{ Jarak } & \multicolumn{4}{c}{ Pemanfaatan Posyandu Lansia } \\
\cline { 2 - 5 } Fasilitas & \multicolumn{2}{c}{ Tidak } & \multicolumn{2}{c}{ Iya } & $p$ \\
\cline { 2 - 5 } Kesehatan & n & $\%$ & n & $\%$ & \\
\hline$>500 \mathrm{M}$ & 11 & 27,5 & 3 & 7,50 & 0.000 \\
& & & & & \\
\hline$<500 \mathrm{M}$ & 4 & 10,0 & 22 & 55,0 & \\
\hline
\end{tabular}

Hasil tabulasi silang memperoleh nilai $p=0,000$, yang menunjukkan bahwa ada hubungan jarak fasilitas kesehatan lansia 
hipertensi dengan Pemanfaatan Posyandu Lansia di Desa Muntoi.

\section{Pembahasan}

Berdasarkan hasil penelitian dari total 40 responden didapatkan nilai signifikan $\mathrm{p}$ value $=$ $0,000 \propto(0,000<0,05)$ demikian disimpulkan bahwa terdapat hubungan yang signifikan antara variabel jarak Fasilitas Kesehatan lansia dengan Pemanfaatan Posyandu Lansia di Desa Muntoi Kecamatan Passi Barat.

Penyakit hipertensi dapat di pengaruhi oleh beberapa faktor salah satunya pengetahuan dan motivasi untuk menurunkan derajat risiko hipertensi agar komplikasi hipertensi dapat dicegah. Segala upaya harus dipertahankan salah satunya pelaksanaan posyandu lansia ${ }^{4}$.

Kepatuhan lansia untuk melakukan diet hipertensi sangat berpengaruh pada dorongan atau motivasi yang di berikan langsung di tempat penyedia atau posyandu lansia ${ }^{5}$. Demikian jarak akan menentukan intensitas lansia untuk mengunjungi posyandu lansia yang dilaksanakan di tempat penyedia pelayanan kesehatan.

Hal ini sejalan dengan penelitian dari hasil study Tamimi 2016 dan Napira 2017 dimana jaminan kesehatan mempengaruhi jumlah kehadiran lansia ke posyandu lansia. Hal ini disebabkan status ekonomi yang rendah, sehingga para lansia tidak memiliki jaminan kesehatan Mandiri, karena disebabkan keterbatasan biaya sehingga mobilisasi lansia untuk mengakses penyedia layanan kesehatan juga terbatas. Pemanfaatan puskesmas dan pelaksanaan programnya sangat bergantung pada fasilitas yang diberikan atau disediakan kepada masyarakat ${ }^{9}$. Hal ini menjadikan pertimbangan masyarakat dan lansia khususnya ketika memutuskan untuk berkunjung ke fasilitas kesehatan.

Jarak puskesmas yang cukup jauh dari tempat tinggal lansia menyebabkan lansia enggan berkunjung ke puskesmas sehingga lebih cenderung memilih pengobatan alternatif dukun yang di nilai lebih efisien dan tidak memerlukan biaya lebih untuk transportasi yang harus dikeluarkan ${ }^{3}$. masyarakat yang memiliki jarak tempat tinggal dekat lebih cenderung berkunjung ke puskesmas dibandingkan dengan masyarakat yang memiliki jarak tempat tinggal jauh $^{6}$.

\section{SIMPULAN DAN SARAN}

\section{Simpulan}

Jarak fasilitas posyandu lansia berdampak positif terhadap pemanfaatan posyandu lansia di Desa Muntoi kecamatan Passi barat. Lansia yang wajib mengikuti posyandu lansi di desa Muntoi sebagian besar $60 \%$ berumur $\geq 69$ tahun dan 40\% lainnya telah berumur 60-68 tahun. Sebagian besar lansia tidak dapat mengakses posyandu lansia apabila memiliki jarak yang $\geq$ $500 \mathrm{M}$ dari tempat tinggalnya.

\section{Saran}

Diharapkan bagi penyedia dan pelaksana layanan kesehatan lansia agar memberi 
dukungan mobilisasi kepada setiap lansia di desa

Muntoi agar mendapatkan pelayanan kesehatan yang efektif dan efisien, demi terciptanya drajat kesehatan lansia yang lebih baik.

\section{REFERENSI}

1. World Health Organiszation (WHO). Global Brief on Hypertension: Silent Killer. Glonal Public Heath Crisis. 2015. [Online] Available at: https://www.who.int/ about/what-we-do/global-of-public-health. [Accessed 25 Oktober 2019].

2. Andaria, K. Hubungan Antara Perilaku Olahraga, Stres dan Pola Makan Dengan Tingkat Hipertensi pada Lanjut Usia di Posyandu Lansia Kelurahan Gerbang Putih Kecamatan Sukolilo Kota Surabaya. Jurnal promkes, 2015: 2(1), pp. 20-32.

3. Departeman Kesehatan RI, Laporan Hasil Riset Kesehatan Dasar (RISKESDA) Indonesia, 2014: Departemen Kesehatan. 2014.

4. Langingi, A.R. Upaya Peningkatan Pengetahuan Masyarakat Tentang Pencegahan Hipertensi Desa Muntoi Kabupaten Bolaang Mongondow. Jurnal Salam Sehat Masyarakat (JSSM), 2020: 1(2), pp. 13-18.

5. Agriana, Rini, S. S. \& Hairitama, R. Kepatuhan Lansia Penderita Hipertensi dalam Pemenuhan Diet Hipertensi. Jurnal Sorot, 2015: 6(3), pp. 46-53.

6. Kementerian Kesehatan RI. Gambaran kesehatan Lansia di Indonesia. [Online] 2013. Available at: http://www.depkes. go.id [Accessed 5 februari 2019].

7. Mubarak. Ilmu Keperawatan Komunitas: Konsep dan Aplikasi. 1 ed. Jakarta: Salemba Medika. 2015.

8. Azizah, L. M. Keperawatan Lanjutan Usia. 1 ed. Yogyakarta: Graha Ilmu. 2011.
9. Sudirman. Work Motivation and Achievement of Health Officers in Basic Program Public Health Center in Sojol Distric. Health Notions, 2018: 2(4), pp. 450452.

10. Anggara \& Prayitno, N. Faktor-Faktor yang berhubungan Dengan Tekanan Darah di Puskesmas Telaga Murni. Jurnal Ilmiah Kesehatan, 2015: 1(5), pp. 12-28.

11. Budiman \& Riyanto, A. Kapita Selekta Kuesioner Pengetahuan dan Sikap dalam Penelitian Kesehatan. 1 ed. Jakarta: Salemba Medika. 2013.

12. Diyono, Kristanto, B. A. \& Prasetyo, C. B. Hubungan Antara Pengetahuan Tentang Hipertensi Dengan Tindakan Mengontrol Tekanan Darah Pada Warga Dukuh Bantulan Desa Jembungan Kecamatan Banyudono Boyolali. KOSALA Jurnal Ilmu Kesehatan, 2015: 1(2), pp. 9-13.

13. Hasugian, F. H., Lubis, N. L. \& T. Hubungan Perilaku Lansia Dan Dukungan Keluarga Terhadap Pemanfaatan Posyandu Lansia Di Wilayah Kerja Puskesmas. Jurnal Promosi Kesehatan dan Biostatistik, 2012: 1(1), pp. 30-42.

14. Kementerian Kesehatan RI. Pedoman Pembinaan Kesehatan Usia Lanjut Bagi Petugas Kesehatan. 1 ed. Jakarta: Kemenkes RI. 2015.

15. Kurniadi, H. \& Nurrahmani, U. Stop! Diabetes, Hipertensi, Kolestrol Tinggi, jantung Koroner. 1 ed. Yogyakarta: Istana Media. 2015.

16. Syahrini, E. N., Susanto, H. S. \& Udiyono, A. Faktor-Faktor Risiko Hipertensi Primer Di Puskesmastlogosari Kulon Kota Semarang. Jurnal kesehatan Masyarakat (JKM) UNDIP, 2012: 1(2), pp. 315-325.

17. Triyanto, E. Pelayanan Keperawatan Bagi Penderita Hipertensi Secara Terpadu. 1 ed. Yogyakarta: Graha Ilmu. 2014. 